Gazi University
Journal of Science
$\mathrm{http} / /$ dergipark.gov.tr/gujs

\title{
Integration of Solar and Wind Based DGs with DSTATCOM in Distribution Systems using Modified Bat Algorithm
}

\author{
Balamurugan POTTUKKANNAN ${ }^{1,}$ (D) , Yuvaraj THANGARAJ ${ }^{1 *}$ (D) , Devabalaji KALIYAPERUMAL ${ }^{2}$ (D) \\ Mohamed Imran ABDUL RASHEED ${ }^{3}$, Muthukannan PETHA PERUMAL ${ }^{1}$
}

${ }^{1}$ Saveetha School of Engineering, Saveetha Institute of Medical and Technical Sciences, Department of Electrical and Electronics Engineering, Chennai, India

${ }^{2}$ Hindustan Institute of Technology and Science, Department of Electrical and Electronics Engineering, Chennai, India

${ }^{3}$ Vellore Institute of Technology, Department of Electrical and Electronics Engineering, Chennai, India

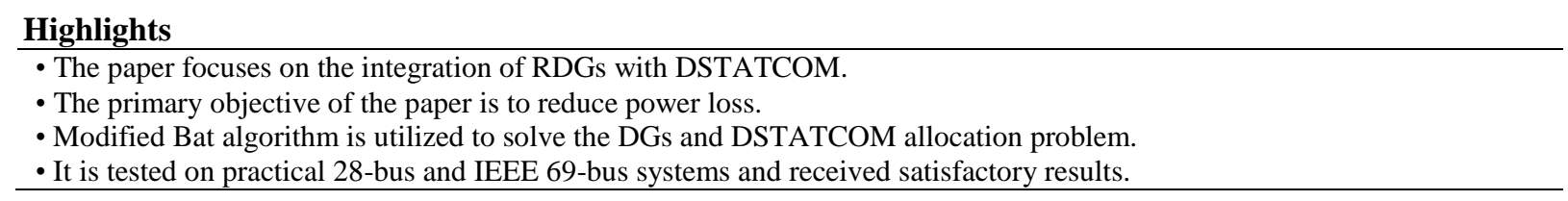

\begin{tabular}{l} 
Article Info \\
\hline \\
Received: $27 / 11 / 2017$ \\
Accepted: 10/09/2018 \\
Keywords \\
\hline REDGs \\
DSTATCOM \\
Radial Distribution \\
System \\
Modified Bat Algorithm
\end{tabular}

\begin{abstract}
Nowadays, renewable energy sources based distributed generations (REDGs) interconnection with distribution system is gaining more attention by the power system engineers since it meets increasing load demand and cancel out environmental threats. Suitable incorporation of REDGs in radial distribution system (RDS) is vital in ensuring qualitative network operational profits. In this present approach a modified bat algorithm (MBA) based optimization method is employed to allocate solar and wind DGs along with DSTATCOM in RDS. The proposed new multi objective function to mitigate power loss, bus voltage development stability betterment and Total Operating Cost (TOC) minimization. Proper modelling of solar irradiance and wind speed have been done in the RDS. The present approach is tested to Indian countrified system structure and standard IEEE 69-bus system, and received satisfactory outputs.
\end{abstract}

\section{INTRODUCTION}

The electric power system scheme is alienated into generation, transmission and distribution systems. Among these distribution system is the final and crucial link in the supply scheme. In India, Majority of distribution networks are radial system and causes high $I^{2} R$ losses and poor voltage profile in the buses. Literatures indicated that the majority of the loss approximately $13 \%$ power production is reduced in the form of $\mathrm{I}^{2} \mathrm{R}$ loss in the distribution network [1-4]. This losses are mitigated by appropriate allocation of compensating devices in RDS.

Due to demand of electrical power rises and unavailability of nonrenewable sources, the installation of the renewable based power generation has became vital role to contribute significant power delivery to consumers. The renewable based power generation such as wind energy, biomass and solar energy has been most commonly used methods. Among these solar power generation and wind based power generation 
technologies are most commonly used because of its natural availability. Inorder to contribute renewable based power generation to meet demand as well as to enhance the bus voltage, one has to place the REDG near to the load.

Even though, situation of these REDGs in the distribution networks cannot guarantee of reactive power support, which would ultimately end up in under voltage at several buses. Further the loads in the distribution networks are inductive in nature which causes lagging power factor. This lagging power factor may increase the instability, mitigate the voltage between the buses and results poor power quality in the distribution network [5-9].

In order to eliminate these problems completely usage of custom power devices (CPD) such as DVR, DSTATCOM, UPQC, and SSTC is done [10]. Through the asisstance of said devices, economical quick fix for reactive power, Power quality improvement and unbalance loading compensation in the distribution network can be smoothly attained [11].D1stribution Static Compensator is parallel connected VSC (Voltage Source Converter) and can be utilized in RDS so as to manage bus voltage to enchance power factor of system as well as reactive power control. Another advantage of the DSTATCOM is that can be able to provide prompt and uninterruptible inductive and capacitive power compensation [1,12]. DSTATCOM can able to acheive to minimize power loss and harmonic content with less price and compact size with other compensating devices.

Optimal allocation of theses compensating devices will guarantee the supreme profits of the system. So the distribution network researchers have to place these REDG and DSTATCOM with optimal allocation in the RDS. There are vast literature review available in the area of DG and DSTATCOM installation with different multi objective functions and metaheuristic techniques.

Actually very few researchers alone tried simultaneous placement of DSTATCOM and DG in RDS [1317]. The multi objective function is to allocate compensating devices in radial networks [13]. The DICANM hybrid algorithm had been adopted to place compensating devices in RDS to minimize losses incurred [14]. Particle swarm optimization was adopted to place compensating devices in radial networks to minimize loss incurred [15]. Exhaustive search optimization techniques was used to utilize to solve concurrent alloted of DSTATCOM and DG [16,17].

On the basis of existing works, it is seen that most of the previous methodologies is greatly used for identification of location and sizing problem of non-renewable compensating devices in the RDS simultaneously. But all the researchers have considered the same objective function for simultaneous allocation of compensating devices in RDS. To use the entire RDS efficiently, it is essential to incorporate both DG and DSTATCOM with a multi objective of mitigating losses incurred, operational expenses, stability enhancement and the bus voltage augmentation of the system. Also researchers have failed to consider REDG units with DSTATCOM.

Recently, a new nature inspired bat algorithm (BA) had been utilized in $[18,19]$ based on echolocation behavior of bats. BA was established in utilizing benefits of previous step by step procedures and other fascinating attributes motivated in the way of behavior of echolocation of micro bats. Compared to other algorithms BA gives better accurateness and efficacy. Even though, its failure rate is very high and the reason is that the bat is not capable to sort out every ways in the hunting area.

So, to resolve above said drawback BA should have been modified. In MBA, the movement of bat is improved with the help of chemotactic activity of bacterium, for discovering optimum results so as that direction the bat can not move. The present MBA can be much better than compared with the original BA in terms of CPU and level of attainment at localized nodes since the MBA sort out hunting area more very effectively.

The above said reason motivated the author to introduce a novel, quick and well efficient bio inspired modified bat optimization algorithm used to provide optimal solution to DSTATCOM and REDG placement in radial networks. The new multi objective function has been introduced to mitigate losses 
incurred, enchance voltage profile, operating cost and maximize VSI. The optimal allocation of DSTATCOM and REDG has been calculated using MBAT. The feasibility and efficiency of the present approach have been verified with standard 69-bus test systems and Indian rural distribution 28 bus systems.

\section{FORMULATION OF THE PROBLEM}

\subsection{Power flow analysis}

In the distribution system the (Resistance/ Reactance) ratio will be high when compare to transmission system. Hence the normal load flow analysis such as Cannot be used. Therefore for the distribution system there is separate load flow analysis called distribution load flow analysis [20].

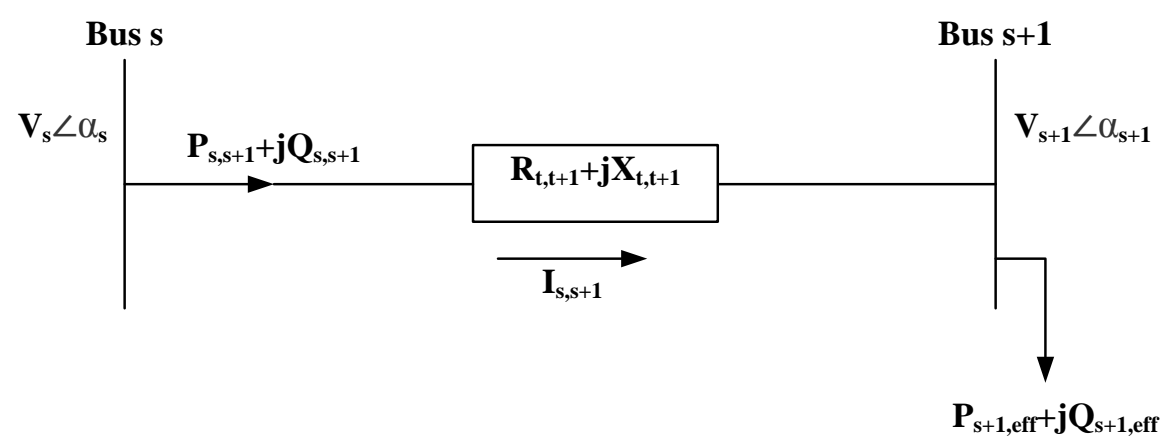

Figure 1. Sample of RDS

In order to understand the proposed approach in simple manner, the author considered only two busses. These two busses can be connected by branch as shown in Figure 1. The power equation of real $\mathrm{P}_{\mathrm{s}, \mathrm{s}+1}$ and reactive $\mathrm{Q}_{\mathrm{s}, \mathrm{s}+1}$ are given below:

$P_{s, s+1}=P_{s+1, e f f}+P_{L o s s(s, s+1)}$,

$Q_{s, s+1}=Q_{s+1, e f f}+Q_{\text {Loss }(s, s+1)}$,

where $P_{s, s+1}$ and $Q_{s, s+1}$ are "active and reactive power flowing through in line between buses" $t$ and $t+1$, $P_{s+1, e f f}$ and $Q_{s+1, \text { eff }}$ are "the total effective real and reactive power supplied beyond the bus" $t+1, P_{\text {Loss }(s, s+1)}$ and $Q_{\text {Loss }(s, s+1)}$ are "active and reactive power losses between buses $t$ and $t+1$ respectively".

The current flow between two buses are determined using (3) and (4)

$\mathrm{I}_{\mathrm{s}, \mathrm{s}+1}=\left(\frac{\mathrm{P}_{\mathrm{s}, \mathrm{s}+1}-j \mathrm{Q}_{\mathrm{s}, \mathrm{s}+1}}{\mathrm{~V}_{\mathrm{s}+1} \angle-\alpha_{\mathrm{s}+1}}\right)$

Also,

$\mathrm{I}_{\mathrm{s}, s+1}=\left(\frac{\mathrm{V}_{\mathrm{s}} \angle \alpha_{\mathrm{s}}-\mathrm{V}_{\mathrm{s}+1} \angle \alpha_{\mathrm{s}+1}}{R_{s, s+1}+j X_{s, s+1}}\right)$

From the equations (3) and (4), 
$V_{s}^{2}-V_{s} V_{s+1} \angle\left(\alpha_{s+1}-\alpha_{s}\right)=\left(\mathrm{P}_{\mathrm{s}, s+1}-j \mathrm{Q}_{s, s+1}\right)\left(R_{s, s+1}+j X_{s, s+1}\right)$.

By relating the both real and imaginary section on each sides of Equation (5) is written as

$$
\begin{aligned}
& V_{s} V_{s+1} * \cos \left(\alpha_{s+1}-\alpha_{s}\right)=V_{s}^{2}-\left(\mathrm{P}_{\mathrm{s}, \mathrm{s}+1} R_{s, s+1}+Q_{s, s+1} X_{s, s+1}\right), \\
& V_{s} V_{s+1} * \sin \left(\alpha_{s+1}-\alpha_{s}\right)=Q_{s, s+1} R_{s, s+1}-\mathrm{P}_{\mathrm{s}, s+1} X_{s, s+1} .
\end{aligned}
$$

By taking sqaure on both side as well as add the Equations (6) and (7), then the new equation can be written as

$$
V_{s+1}^{2}=V_{s}^{2}-2\left(\mathrm{P}_{\mathrm{s}, \mathrm{s}+1} R_{s, s+1}+Q_{s, s+1} X_{s, s+1}\right)+\left(R_{s, s+1}^{2}+X_{s, s+1}^{2}\right)\left(\frac{\mathrm{P}_{\mathrm{s}, \mathrm{s}+1}^{2}+\mathrm{Q}_{\mathrm{s}, s+1}^{2}}{\left|\mathrm{~V}_{\mathrm{t}}\right|^{2}}\right) .
$$

The real and apparent losses incurred in line section between buses $s$ and $s+1$ are determined as

$$
\begin{aligned}
& \mathrm{P}_{\mathrm{Loss}(\mathrm{s}, \mathrm{s}+1)}=I_{s, s+1}^{2} * \mathrm{R}_{\mathrm{s}, \mathrm{s}+1}, \\
& \mathrm{P}_{\mathrm{Loss}(\mathrm{s}, \mathrm{s}+1)}=\left(\frac{\mathrm{P}_{\mathrm{s}, \mathrm{s}+1}^{2}+\mathrm{Q}_{\mathrm{s}, \mathrm{s}+1}^{2}}{\left|\mathrm{~V}_{\mathrm{t}+1}\right|^{2}}\right) * \mathrm{R}_{\mathrm{s}, \mathrm{s}+1}, \\
& \mathrm{Q}_{\mathrm{Loss}(\mathrm{t}, \mathrm{t}+1)}=I_{t, t+1}^{2} * \mathrm{X}_{\mathrm{t}, \mathrm{t}+1}, \\
& \mathrm{Q}_{\mathrm{Loss}(\mathrm{s}, \mathrm{s}+1)}=\left(\frac{\mathrm{P}_{\mathrm{s}, \mathrm{s}+1}^{2}+\mathrm{Q}_{\mathrm{s}, \mathrm{s}+1}^{2}}{\left|\mathrm{~V}_{\mathrm{s}+1}\right|^{2}}\right) * \mathrm{X}_{\mathrm{s}, \mathrm{s}+1} .
\end{aligned}
$$

The total real and apparent losses incurred in distribution networks are given as:

$$
\begin{aligned}
& \mathrm{P}_{\mathrm{TL}}=\sum_{\mathrm{t}=1}^{\mathrm{Nb}} \mathrm{P}_{\mathrm{Loss}(\mathrm{s}, \mathrm{s}+1)}, \\
& \mathrm{Q}_{\mathrm{TL}}=\sum_{\mathrm{t}=1}^{\mathrm{Nb}} \mathrm{Q}_{\operatorname{Loss}(\mathrm{s}, \mathrm{s}+1)},
\end{aligned}
$$

where $N b$ is overall number of branches.

\subsection{Power loss reduction using REDG/DSTATCOM placement}

The active power loss minimization will largley minimize the intake the power from substation. If the DSTATCOM and REDG optimally placed in the distribution systems, then the losses incurred is minimized. The total power losses can be reduced using (15)

$$
\Delta \mathrm{P}_{T L}^{\mathrm{REDG} / \mathrm{DST}}=\frac{\mathrm{P}_{T L}^{\mathrm{REDG} / \mathrm{DST} T}}{\mathrm{P}_{\mathrm{TL}}}
$$


The total real losses incurred can be decreased using REDG/DSTATCOM situation in the RDS can be maximized on minimizing $\Delta \mathrm{P}_{T L}^{\mathrm{REDG} / \mathrm{DST}}$.

\subsection{Total Voltage Deviation (TVD)}

The other advantage in placing DSTATCOM and REDG in radial networks is to maintain the voltage profile across load. While placing the compensating devices one has to keep in mind that the voltage level should not go beyond the allowable limits [21].

\subsubsection{Bus voltage improvement using TVD}

In order to check the improvement of the bus voltage after placing compensating devices. It is necesary to check the system with using TVD [22]. If the value of the TVD is minimized and near to zero, then voltage profile is good. When TVD is near to zero then the distribution network is said to be stable in nature. The voltage level of the system with REDG/DSTATCOM allocation is maximized on minimizing $\Delta \mathrm{TVD}^{\mathrm{REDG} / \mathrm{DST}}$. The TVD of the system can be calculated using

$\Delta \operatorname{TVD}^{\text {REDGDST }}=\frac{\operatorname{TVD}_{a f t e r}^{\text {REDGST }}}{\text { TVD }_{\text {before }}}$,

where $\mathrm{TVD}_{\text {before }}$ is the TVD before the allocation of REDG/DSTATCOM and $\mathrm{TVD}_{\text {after }}^{\mathrm{REDG} / \mathrm{DST}}$ is the total voltage deviation after the allocation of REDG/DSTATCOM in the RDS.

\subsection{Voltage Stability Index (VSI)}

The voltage stability index can be used to check the voltage profile of network are within its limits are not. If the vlaue of the voltage stability of the system is very less then it means the system is said to be very weak. Alternatively if the VSI of the system is high then the system is said to be having good voltage profile [23]. The VSI can be refereed as the capability of the system to regulate the voltage profile within the statisfactory level. The voltage stability of the system can also be maximized on opimal placement of REDG and DSTATCOM.

The node VSI can be determined suing Equation (17). The bus which have low VSI can be selected to place compensating devices

$$
V S I(s+1)=\left|V_{s}\right|^{4}-4\left[P_{s+1, e f f} * X_{t}-Q_{s+1, e f f} * R_{s}\right]^{2}-4\left[P_{s+1, e f f} * R_{s}+Q_{s+1} * X s\right]\left|V_{s}\right|^{2} .
$$

\subsubsection{Voltage stability index maximization through allocation of REDG/DSTATCOM}

Voltage stability index can be maximized on allocation of DSTATCOM/REDG in the radial network. It is taken as the ratio of VSI with and without REDG/DSTATCOM installation in the RDS, and is formulated as

$$
\Delta \mathrm{VSI}^{\mathrm{REDG} / \mathrm{DST}}=\frac{\mathrm{VSI}_{\text {after }}^{\mathrm{REDGIDST}}}{\mathrm{VSI}_{\text {before }}},
$$

VSI is maximized on maximizing $\Delta \mathrm{VSI}{ }^{\text {REDG/DST }}$.

\subsection{Operational cost minimization}


The DISCOs will decide the operational cost by using standared rates, operating cost of DGs. The operational expense is divided into two parts. One is the expense associated with real power and another is the cost associated with reactive power.

This cost can be reduced by optimal placement of REDG/DSTATCOM . Therefore, the total operating expenses is formulated as

$$
T O C=\left(a_{1} \mathrm{P}_{T L}^{\mathrm{REDG} D S T}\right)+\left(a_{2} \mathrm{P}_{T L}^{\mathrm{REDG} D S T}\right),
$$

where $a_{1}$ and $a_{2}$ are the "cost coefficients of the real/reactive power provided by the substation and REDG/DSTATCOM" in $\$ / \mathrm{kW} / \mathrm{kVAr}$. $\mathrm{P}_{\mathrm{REDG} / \mathrm{DST}}$ is the "total real/reactive power taken from installed REDG/DSTATCOM". The net operating expense reduction of REDG/DSTATCOM is determined as

$$
\Delta O C=\frac{\mathrm{TOC}}{\mathrm{a}_{2} P_{R E D G / D S T}^{\max }} .
$$

The TOC of network with REDG/DSTATCOM placement minimized on minimizing $\triangle O C$.

\subsection{Multi-objective function}

Mathematically, proposed MOF for appropriate allocation of REDG and DSTATCOM with equality and inequality constraints is defined below

$$
\operatorname{Minimize}(F)=\operatorname{Min}\left(\beta_{1} \Delta \mathrm{P}_{T L}^{\mathrm{REDG}}+\beta_{2} \Delta T V D^{R E D G / D S T}+\beta_{3}\left(1 / \Delta \mathrm{VSI}^{\mathrm{REDG} I S T}\right)+\beta_{4} \Delta \mathrm{TOC}\right),
$$

where $\beta_{1}, \beta_{2}, \beta_{3}$ and $\beta_{4}$ are the weighting aspects corresponding to respective losses incurred, TVD minimization, TOC minimization, and VSI maximization

$$
\sum_{j=1}^{4} \beta_{j}=1^{\wedge} \beta_{j} \in[0,1] .
$$

The weights are calculated to provide consistent priority to every impacting factors in REDG/DSTATCOM installation and on the basis of essential analysis (e.g., operation and planning) [24, 25]. The authors took weight for minimization of minimization of losses incurred is $0.4\left(\beta_{1}=0.4\right)$, weight for TVD minimization is $0.2\left(\beta_{2}=0.2\right)$ and weight for voltage stability maximization is $0.2\left(\beta_{3}=0.2\right)$ weight for total operating cost (TOC) is $0.2\left(\beta_{4}=0.2\right)$.

\section{MODELING OF WIND AND SOLAR}

Based on the model and resource like wind speed, solar radiation and ambient temperature the generating power of wind turbine generation unit (WTGU) and photovoltaic (PV) array have been decided. In the following section explain the modelling concept of WTGU and PV array to realize REDGs placement in the RDS in efficient way. The modelling of windand solar has been taken from [26].

\section{BAT ALGORITHM}




\subsection{Modified Bat Algorithm (MBA)}

The modified bat algorithm (MBA) concept can be derived by combining original BA and bacterial foraging strategies. In MBA, the bacterial foraging algorithm (BFO) technique is inspired to generate the new solutions using the equations. A complete explanation of the BFO can be found in [27-29]. In the MBA, The fitness function will be used to select the movement of bat. Swimming in BAT algorithm is nothing but the moving bats to optimal value of fitness function. If not, the bat will follow chemotatic movement of bacterium. This movement can be calculated using (23)

$$
x_{i}^{t}=x_{i}^{t-1}+v_{i}^{t} \frac{\Delta_{i}}{\sqrt{\Delta_{i}^{T} \times \Delta_{i}}} .
$$

From the above, $v_{i}^{t}$ is velocity at time step $t$ determined and $\Delta_{i}$ is represented by its arbitrary numeral which will produce the numerical values in the range $[-1,1]$. The flow chart of modified Bat algorithm is depicted in Figure 2. In main bat algorithm swimming procedure only will be possible. Whereas in case of modified bat algorithm both the swimming and tumbling can be acheived. Here tumbling referes to movement of bat in random direction. If the bat acheived its goal then the chemotactic movement will come to end. If the bat is in the non appearance of the falling activity then bat is not allowed to move in every direction of search space which results in unproductive role.

\subsection{Steps for implementation of proposed work by using MBA}

Step 1: Initially, fed the system bus data and distribution load flow.

Step 2: Obtain power losses without compensation, Voltage Stability Index (VSI) and voltage value at each buses.

Step 3: Determine the REDG/DSTATCOM locations by using MBA.

Step 4: Keep the lower and higher limits for Bat algorithm as a control parameters and to set the maximum allowable iteration. [Set pulse rates, loudness and pulse frequency]. 


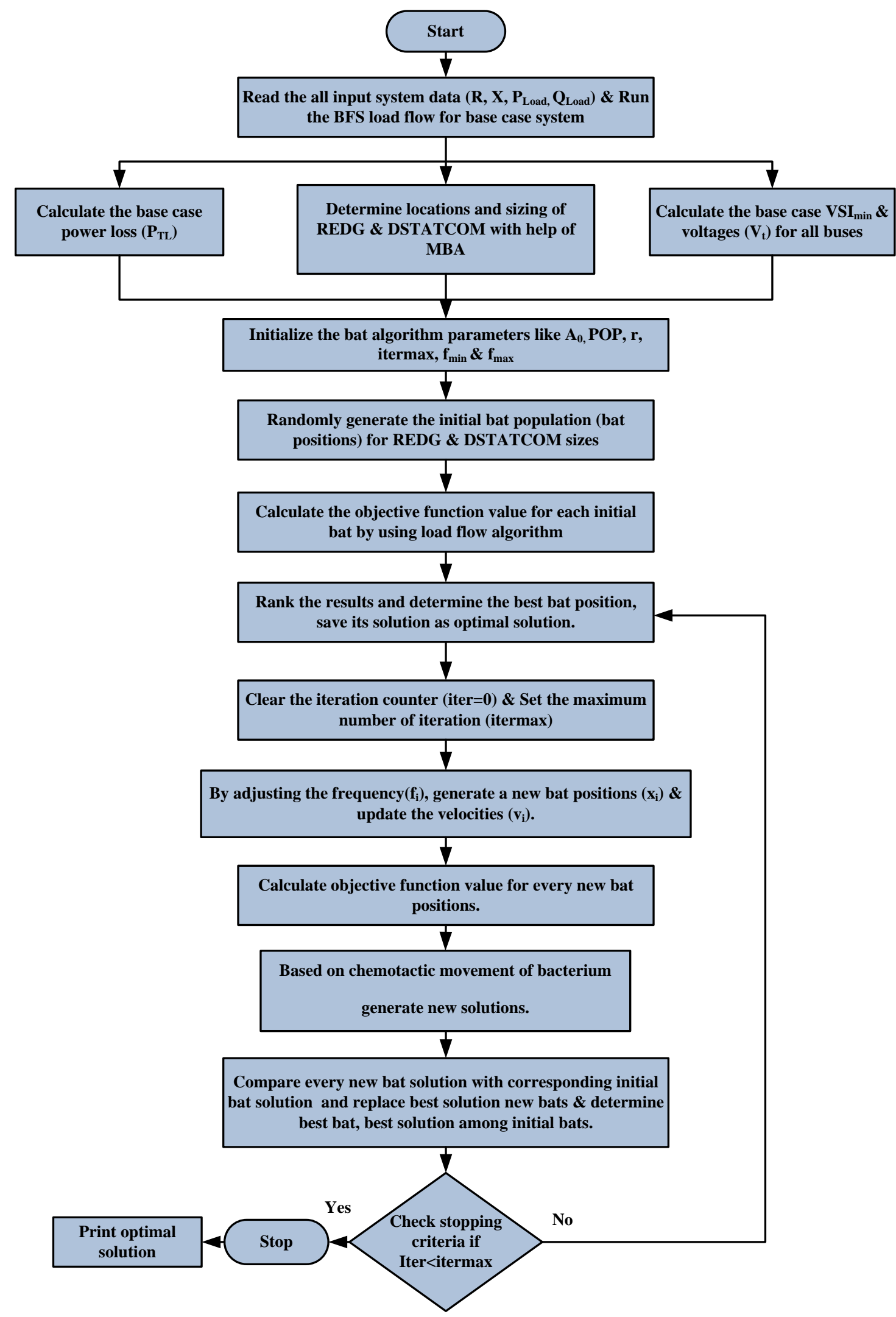

Figure 2. Flowchart for implementing modified bat algorithm 
Step 5: Initiate random population of each bat in the targeted area. Each and every optimal bat gives excellent outputs in terms of $\mathrm{kW}$ or KVAr for DG/DSTATCOM in RDS.

Step 6: To find the best fitness function values. In this process, distribution load flow method is used to determine the predictable value of the losses incurred and the voltage magnitude of the objective function to every result or bat.

Step 7: Select finest bat in population i.e., which have minimum value of losses incurred.

Step 8: Bat population can be updated.

Step 9: Again run distribution load flow analysis and note down the real loss incurred and reactive loss incurred with updated bat population.

Step 10: Based on chemotactic movement of bacterium (Concept is derived from [20]), generate new solutions with help of equation (38).

Step 11: In this step the algorithm termination can be decided as soon as criteria reached. The condition for termination of the program will be depends on the maximum iteration to update bat population values or else minimized objective function value can be reached. If this condition acheived then stop the bat algorithm or else retuen to step No. 5.

Step 12: Show best values of the objective function.

These steps are continued to mitigate the OF value.

\section{SIMULATION RESULTS AND DISCUSSION}

The superiority of the developed MBA based optimization method is studied for two different distribution networks such as 28-bus rural Indian and standard IEEE 69 bus RDS. The simulated values of 28 and 69bus RDS are elaborated below in brief. The present approach has been performed via Matlab.

\subsection{Indian 28-Bus Rural Distribution System}

In order to check the reliability of the proposed approach, the real time system of $11 \mathrm{KV}$ Indian 28 -bus distribution networks has been considered. The selected network is radial in nature with consists of 28buses and feeders is considered to be first bus as given in Figure 3. Required loads of power lines are adopted from [30, 31]. BFS algorithm is employed to calculate base case values. In the proposed method PV and wind based renewable DGs are taken along with DSTATCOM in the RDS to get required objective.

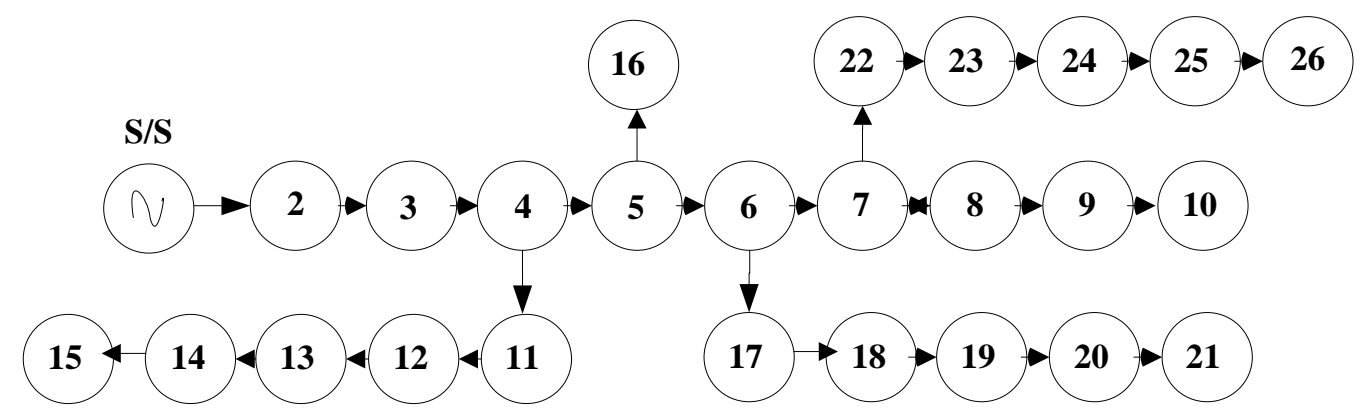

Figure 3. Sample Indian 28-bus distribution network

To analysis the effectiveness of the proposed approach in Indian 28-bus rural and IEEE 69-buses have been taken and analyzed with four different scenarios:

Scenario (i): Base case,

Scenario (ii): DSTATCOM compensation,

Scenario (iii): REDG compensation,

Scenario (iv): REDG \& DSTATCOM compensation.

\subsubsection{Scenario -I}

In this scenario, the system base case voltages and loss are arrived without consideration of any compensating devices in the RDS. The loss, lower bus voltage, VSI and TVD are $68.88 \mathrm{~kW}, 0.9123 \mathrm{p} . \mathrm{u}$, 0.6927p.u, 1.7975 . 


\subsubsection{Scenario -II}

An optimized size of two DSTATCOMs are placed at appropriate location $7^{\text {th }}$ and $12^{\text {th }}$ correspondingly. The optimum places of the DSTATCOMs are determined with help of stability values. The losses are mitigated to $33.76 \mathrm{~kW}$ from $68.88 \mathrm{~kW}$ with 0.9473 p.u minimal bus voltage.

\subsubsection{Scenario -III}

By using MBA, two different REDGs (wind-1 and solar-1) are located. After allocating the REDGs, the power loss is mitigated to $6.10 \mathrm{~kW}$. The VSI of the system is amended from 0.6927 p.u to 0.9591 p.u after DG compensation. The TOC of the case is 3474 (\$) and the TVD is nearly zero which ensures the bus voltage enhancement.

Table 1. Simulated results for the 28-bus Indian distribution system

\begin{tabular}{|c|c|c|c|c|c|c|c|}
\hline \multirow[b]{2}{*}{ Items } & \multirow{2}{*}{$\begin{array}{l}\text { Without } \\
\text { Compensati } \\
\text { on }\end{array}$} & \multirow{2}{*}{$\begin{array}{l}\text { With } \\
\text { DSTATCO } \\
\text { M }\end{array}$} & \multicolumn{2}{|c|}{ With REDG } & \multicolumn{3}{|c|}{ With REDG and DSTATCOM } \\
\hline & & & Solar & Wind & Solar & Wind & $\begin{array}{l}\text { DSTATCO } \\
\text { M }\end{array}$ \\
\hline $\begin{array}{l}\text { Size in kW } \\
\text { (Bus No) }\end{array}$ & -------- & -------- & $\begin{array}{l}202 \\
(13)\end{array}$ & $520(8)$ & $198(13)$ & $520(8)$ & -------- \\
\hline $\begin{array}{l}\text { Size in } \\
\text { kVAr (Bus } \\
\text { No) }\end{array}$ & -------- & $\begin{array}{l}509(8) \\
218(13)\end{array}$ & -------- & -------- & -------- & -------- & $218(13)$ \\
\hline $\begin{array}{l}\text { Power } \\
\text { Factor }\end{array}$ & ------- & ------- & Unity & 0.7021 & Unity & 0.7206 & -------- \\
\hline$P_{\text {Loss }}(\mathrm{kW})$ & 68.88 & 32.96 & 5.95 & & 3.26 & & \\
\hline $\begin{array}{l}\% \\
\text { Reduction } \\
\text { in } P_{\text {Loss }}\end{array}$ & ------- & 52.15 & 91.36 & & 95.28 & & \\
\hline$V_{\min }(\mathrm{p} . \mathrm{u})$ & 0.9123 & 0.9481 & 0.9898 & & 0.9992 & & \\
\hline $\begin{array}{l}V S I_{\text {min }} \\
\text { (p.u) }\end{array}$ & 0.6927 & 0.8018 & 0.9582 & & 0.9677 & & \\
\hline Total CVD & 1.7975 & 0.2086 & 0 & & 0 & & \\
\hline TOC & ------- & 3766 & 3588 & & 4523 & & \\
\hline $\mathrm{CPU}(\mathrm{sec})$ & ------- & 8.33 & 9.76 & & 10.11 & & \\
\hline
\end{tabular}

\subsubsection{Scenario -IV}

In Scenario -IV, the candidate locations of the REDGs and DSTATCOMs are identified using VSI and sized using MBA. The maximum loss mitigation has been achieved in this Scenario that is $3.49 \mathrm{~kW}$ with highly improved bus voltage and stability values which is better compared to other considered Scenarios. 


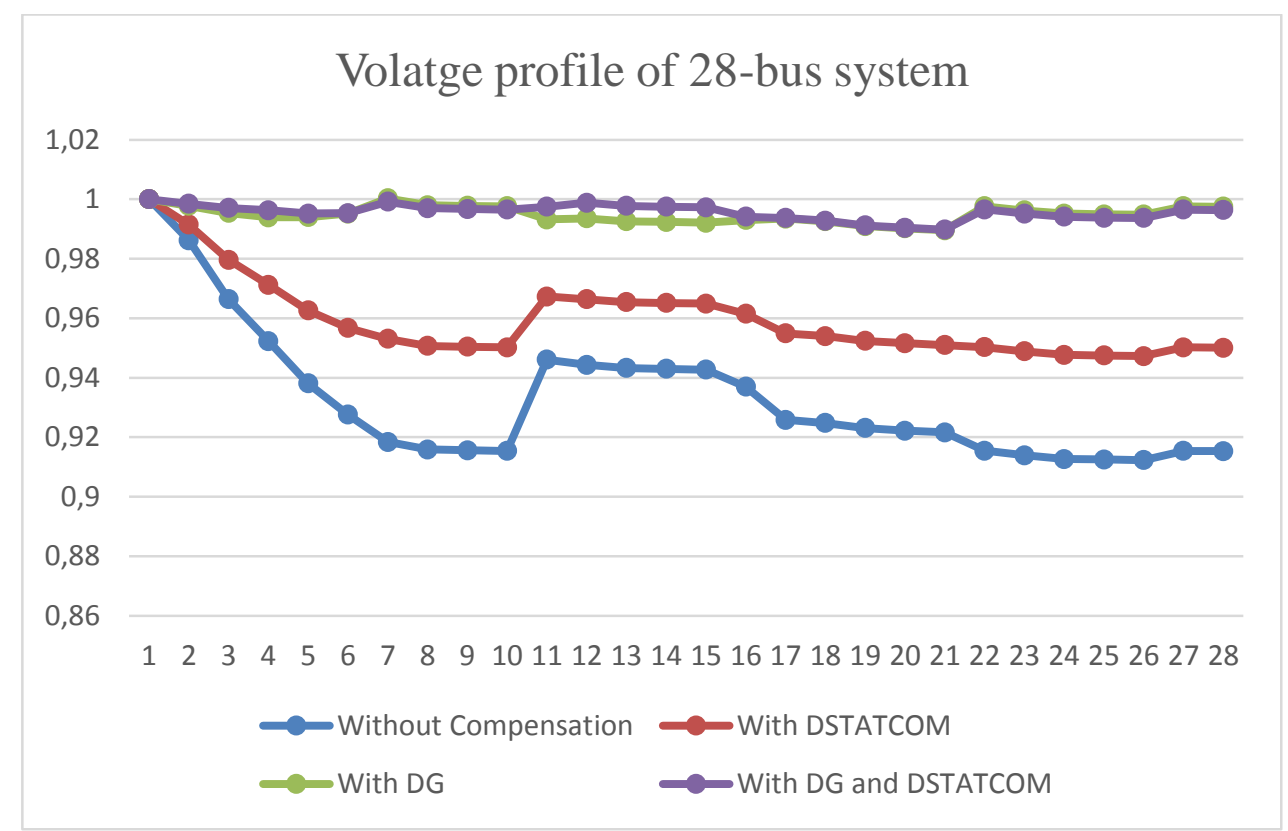

Figure 4. Voltage level of 28-bus Indian distribution system

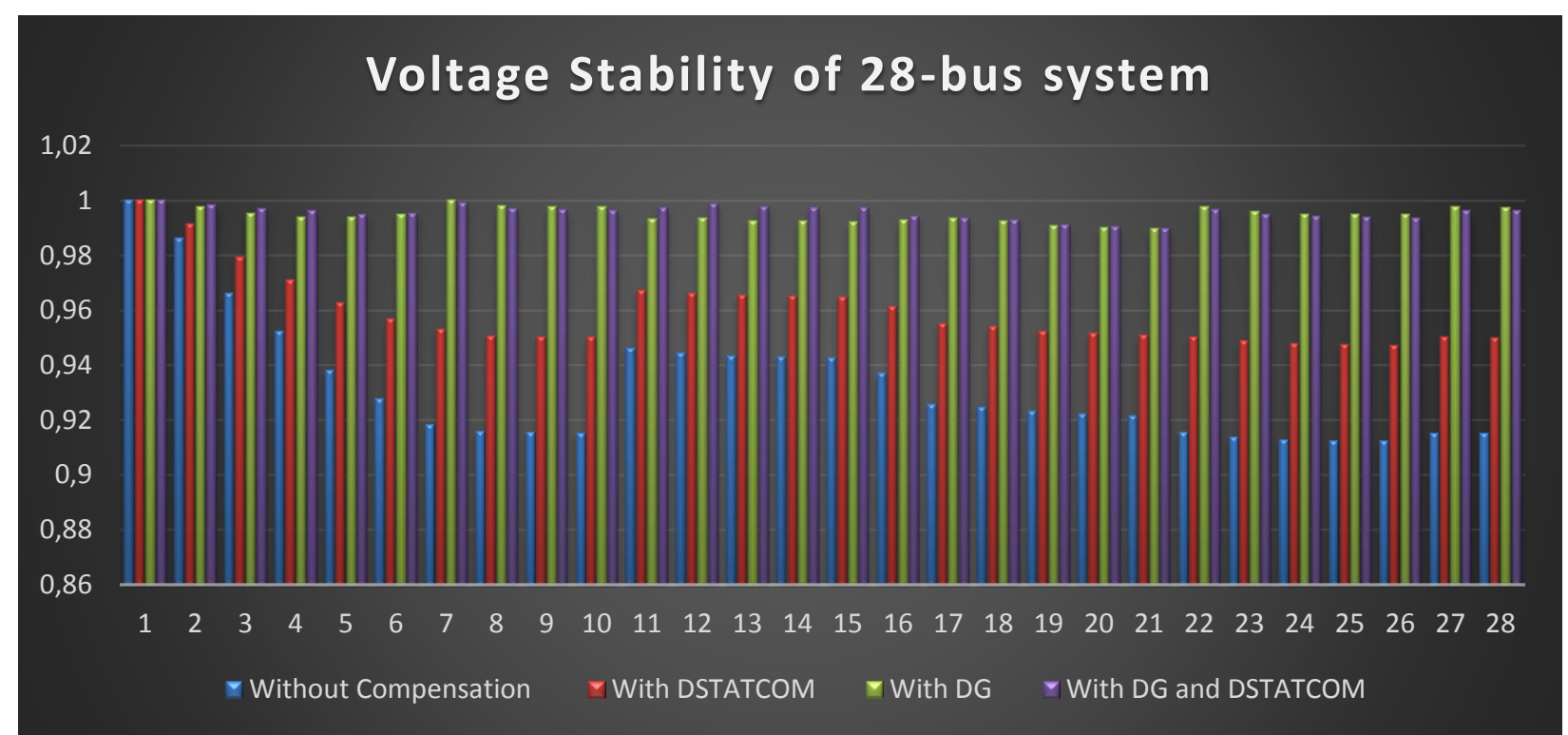

Figure 5. Stability analysis of voltage level of 28-bus Indian distribution network

\subsection{Analysis}

Various parameters along with location and sizes of compensating devices are compared and depicted in Table 1 for different scenarios. Also, bus voltage and system stability development in all buses with various scenarios are depicted in in Figures 4 and 5, respectively. The maximum objective function is attained when both REDGs and DSTATCOM are installed together in RDS. The Table 1, Figures 4 and 5 are proved the above statement.

To demonstration the efficacy of the work, it has been compared with Bat Algorithm (BA) with same objective function values. Since simultaneous placement of REDG and DSTATCOM in RDS is not available in the literature for 28 bus system. So, the authors executed similar objective with BA and equated its results with MBA. From the Table 2, it is concluded that, proposed MBA gives better results compared with BA. 
Table 2. Performance of 28-bus test system

\begin{tabular}{|c|c|c|c|c|}
\hline & & & Proposed Method & BA \\
\hline \multirow{4}{*}{ Case I } & \multirow{4}{*}{$\begin{array}{l}\text { Without } \\
\text { Compensation }\end{array}$} & $\mathrm{P}_{\text {loss }}(\mathrm{kW})$ & 68.88 & 68.88 \\
\hline & & TVD & 1.7975 & 1.7975 \\
\hline & & $\mathrm{VSI}_{\min }(\mathrm{p} . \mathrm{u})$ & 0.6927 & 0.6927 \\
\hline & & $\mathrm{V}_{\min }(\mathrm{p} . \mathrm{u})$ & 0.9123 & 0.9123 \\
\hline \multirow{6}{*}{ Case II } & \multirow{6}{*}{ Only DSTATCOM } & Size in kVAr (location) & $\begin{array}{l}480(7) \\
230(12)\end{array}$ & $\begin{array}{l}570(7) \\
240(12)\end{array}$ \\
\hline & & $\mathrm{P}_{\text {loss }}(\mathrm{kW})$ & 33.76 & 36.56 \\
\hline & & $\% \mathrm{P}_{\text {loss }}$ Reduction & 50.99 & 46.92 \\
\hline & & Total CVD & 0.2086 & 0.3065 \\
\hline & & $\mathrm{VSI}_{\min }(\mathrm{p} . \mathrm{u})$ & 0.8027 & 0.7827 \\
\hline & & $\mathrm{V}_{\min }(\mathrm{p} . \mathrm{u})$ & 0.9473 & 0.8973 \\
\hline \multirow{6}{*}{ Case III } & \multirow{6}{*}{ Only REDG } & Size in kW (location) & $\begin{array}{l}220(12) \\
470(7)\end{array}$ & $\begin{array}{l}310(12) \\
560(7)\end{array}$ \\
\hline & & $\mathrm{P}_{\text {loss }}(\mathrm{kW})$ & 6.10 & 7.35 \\
\hline & & $\% \mathrm{P}_{\text {loss }}$ Reduction & 91.15 & 89.32 \\
\hline & & TVD & 0 & 0 \\
\hline & & $\mathrm{VSI}_{\min }(\mathrm{p} . \mathrm{u})$ & 0.9591 & 0.9341 \\
\hline & & $\mathrm{V}_{\min }(\mathrm{p} . \mathrm{u})$ & 0.9896 & 0.9797 \\
\hline \multirow{7}{*}{ Case IV } & \multirow{7}{*}{$\begin{array}{l}\text { Simultaneous } \\
\text { REDG and } \\
\text { DSTATCOM }\end{array}$} & Size in kVAr (location) & $\begin{array}{l}210(12) \\
460(7) \\
\end{array}$ & $\begin{array}{l}310(12) \\
580(7) \\
\end{array}$ \\
\hline & & Size in kW (location) & $220(12)$ & $260(12)$ \\
\hline & & $\mathrm{P}_{\text {loss }}(\mathrm{kW})$ & 3.49 & 4.08 \\
\hline & & $\% \mathrm{P}_{\text {loss }}$ Reduction & 94.94 & 94.07 \\
\hline & & TVD & 0 & 0 \\
\hline & & $\mathrm{VSI}_{\min }(\mathrm{p} . \mathrm{u})$ & 0.9687 & 0.9560 \\
\hline & & $\mathrm{V}_{\min }(\mathrm{p} . \mathrm{u})$ & 0.9988 & 0.9878 \\
\hline
\end{tabular}

\subsection{IEEE 69-Bus Test System}

To show the efficiency MBA large 69 bus RDS with load of 3.80 MW, 2.69 MVAR are considered in this case. The sample IEEE 69-bus network is depicted in Figure 6 and are obtained from [32].

\subsubsection{Scenario -I}

In this scenario, the system base case voltages and loss are arrived without consideration of any compensating devices in the RDS. The loss, lower bus voltage and VSI are $225 \mathrm{~kW}, 0.9090$ p.u and 0.6822 p.u respectively.

\subsubsection{Scenario -II}

An optimized size of two DSTATCOMs are placed at appropriate location $18^{\text {th }}$ and $61^{\text {st }}$ correspondingly. The optimum places of the DSTATCOMs are determined with help of stability values. The losses are mitigated to $147.27 \mathrm{~kW}$ from $25 \mathrm{~kW}$ with 0.9310 p.u. minimal bus voltage. The TOC of this case is 8690 (\$) and TVD is decreased to 0.5090 p.u. 


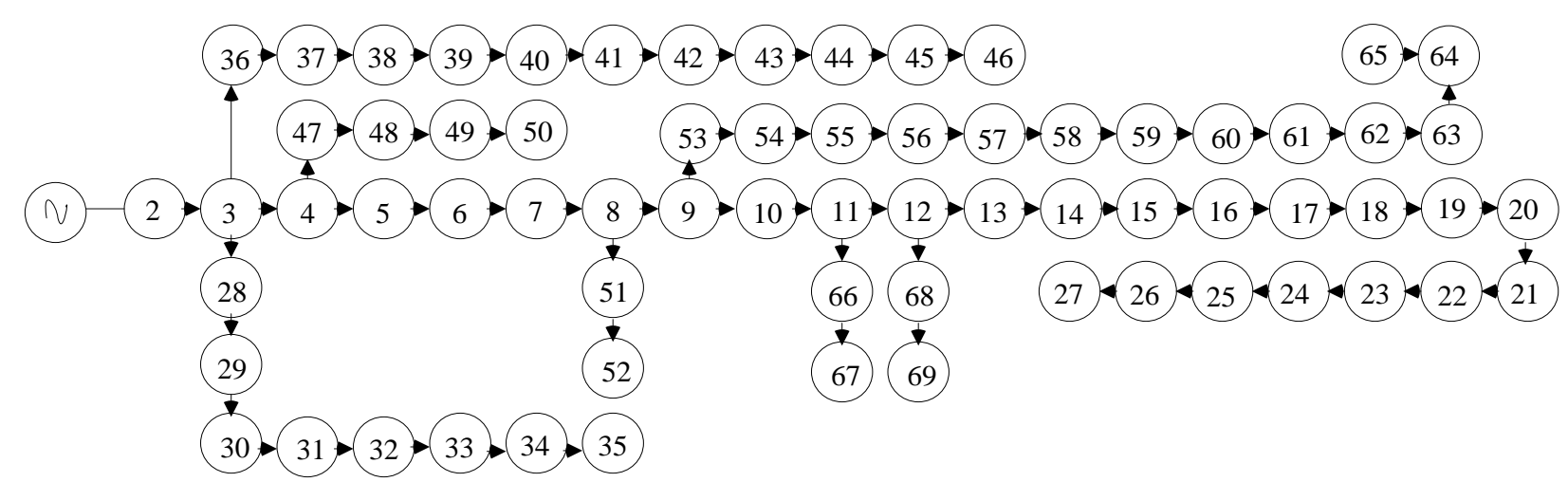

Figure 6. One line diagram of standard IEEE 69-bus network

Table 3. Simulation results for the IEEE 69-bus test system

\begin{tabular}{|c|c|c|c|c|c|c|c|}
\hline \multirow{2}{*}{ Items } & \multirow{2}{*}{$\begin{array}{l}\text { Base } \\
\text { Case }\end{array}$} & \multirow{2}{*}{$\begin{array}{l}\text { DSTATCOM } \\
\text { Compensatio } \\
\text { n }\end{array}$} & \multicolumn{2}{|c|}{$\begin{array}{l}\text { REDG } \\
\text { Compensation }\end{array}$} & \multicolumn{3}{|c|}{$\begin{array}{l}\text { REDG and DSTATCOM } \\
\text { Compensation }\end{array}$} \\
\hline & & & Solar & Wind & Solar & Wind & $\begin{array}{l}\text { DSTATCO } \\
\mathrm{M}\end{array}$ \\
\hline $\begin{array}{l}\text { Size in kW } \\
\text { (Bus No) }\end{array}$ & -------- & -------- & $\begin{array}{l}520 \\
(18)\end{array}$ & $1730(61)$ & $520(18)$ & $\begin{array}{l}1740 \\
(61)\end{array}$ & -------- \\
\hline $\begin{array}{l}\text { Size in } \\
\text { kVAr (Bus } \\
\text { No) }\end{array}$ & -------- & $\begin{array}{l}350(18) \\
1270(61)\end{array}$ & -------- & -------- & -------- & -------- & 350 (18) \\
\hline $\begin{array}{l}\text { Power } \\
\text { Factor }\end{array}$ & -------- & -------- & Unity & 0.8016 & Unity & 0.8165 & -------- \\
\hline$P_{\text {Loss }}(\mathrm{kW})$ & 225 & 147.27 & 13.26 & & 8.37 & & \\
\hline $\begin{array}{l}\% \\
\text { Reduction } \\
\text { in } P_{\text {Loss }} \\
\end{array}$ & -------- & 34.54 & 93.95 & & 96.28 & & \\
\hline$V_{\min }(\mathrm{p} . \mathrm{u})$ & 0.9090 & 0.9310 & 0.9919 & & 0.9942 & & \\
\hline $\begin{array}{l}V S I_{\min } \\
\text { (p.u) }\end{array}$ & 0.6822 & 0.7438 & 0.9587 & & 0.9687 & & \\
\hline Total CVD & 0.7327 & 0.5090 & 0 & & 0 & & \\
\hline TOC(\$) & -------- & 8,690 & 11,300 & & 13,630 & & \\
\hline $\mathrm{CPU}(\mathrm{sec})$ & -------- & 9.45 & 10.63 & & 11.94 & & \\
\hline
\end{tabular}

\subsubsection{Scenario -III}

Two different REDGs (wind-1 \& solar-1) are located and sized in the radial distribution system with help of MBA. After allocating the REDGs, the power loss is mitigated to $13.26 \mathrm{~kW}$. The VSI of the system is amended from 0.6822 p.u to 0.9587 p.u after DG placed.

\subsubsection{Scenario -IV}

In Scenario -IV, the candidate locations of the REDGs and DSTATCOMs are identified using VSI and sized using MBA. The maximum loss mitigation has been achieved in this Scenario that is $8.37 \mathrm{~kW}$ with highly improved bus voltage and stability values which is better compared to other considered Scenarios. 


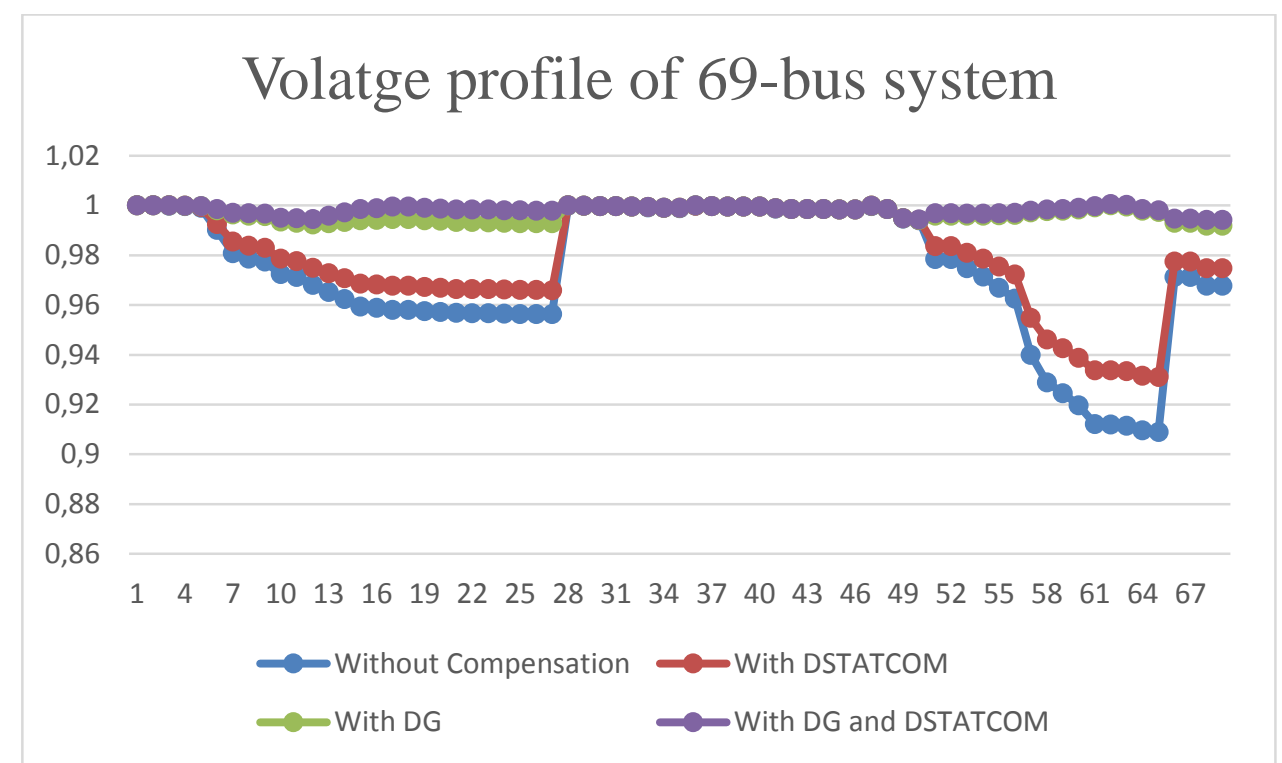

Figure 7. Voltage profile of IEEE 69-bus test system

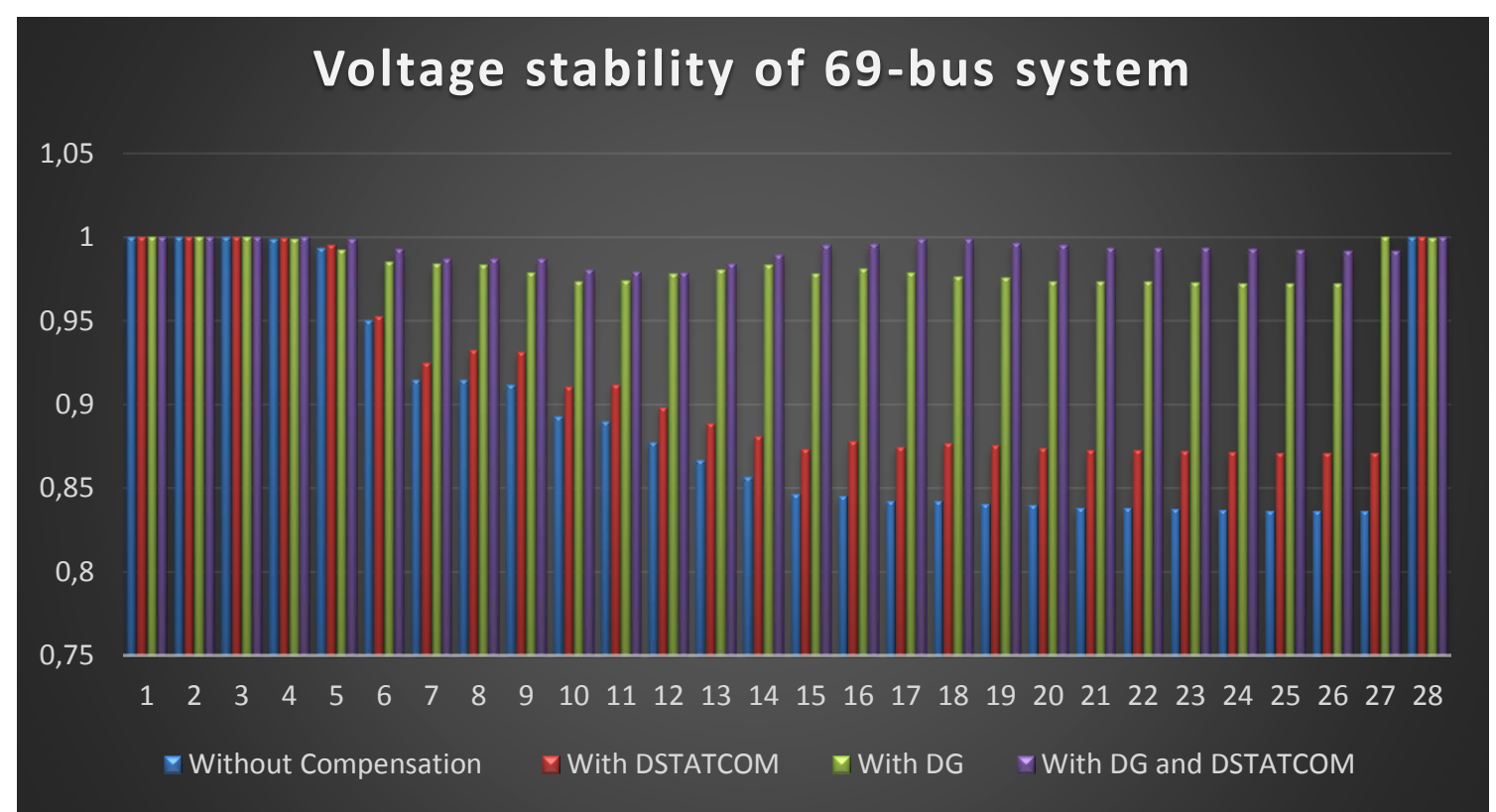

Figure 8. Voltage stability of IEEE 69-bus test system

\subsection{Analysis}

Various parameters along with location and sizes of compensating devices are compared and depicted in Table 3 for different scenarios. Also, bus voltage and system stability development in all buses with various scenarios are depicted in in Figures 7 and 8, respectively. The maximum objective function is attained when both REDGs and DSTATCOM are allocated together in RDS. The Table 3, Figures 7 and 8 are proved the above statement. To demonstration the efficacy of the work, it has been compared with PSO [15] and ICSO [33] and it is depicted Table 4. Compared to other method, the present approach provides improved results in all aspects. 
Table 4. Performance of 69-bus test system

\begin{tabular}{|c|c|c|c|c|c|}
\hline & & & $\begin{array}{l}\text { Proposed } \\
\text { Method }\end{array}$ & ICSO [33] & PSO [15] \\
\hline \multirow{4}{*}{ Case I } & \multirow{4}{*}{$\begin{array}{l}\text { Without } \\
\text { Compensation }\end{array}$} & $\mathrm{P}_{\text {loss }}(\mathrm{kW})$ & 225 & 225 & 225 \\
\hline & & Total CVD & 0.7327 & 0.7327 & 0.7327 \\
\hline & & $\mathrm{VSI}_{\min }(\mathrm{p} . \mathrm{u})$ & 0.6822 & 0.6822 & 0.6822 \\
\hline & & $\mathrm{V}_{\min }(\mathrm{p} . \mathrm{u})$ & 0.9090 & 0.9090 & 0.9090 \\
\hline \multirow{6}{*}{ Case II } & \multirow{6}{*}{ Only DSTATCOM } & $\begin{array}{l}\text { Size in kVAr } \\
\text { (location) }\end{array}$ & $\begin{array}{l}350(18) \\
1270(61)\end{array}$ & $1301(61)$ & 901.1(61) \\
\hline & & $\mathrm{P}_{\text {loss }}(\mathrm{kW})$ & 147.27 & 152.07 & 167.9 \\
\hline & & $\begin{array}{l}\% \mathrm{P}_{\text {loss }} \\
\text { Reduction }\end{array}$ & 34.54 & 32.41 & 25.37 \\
\hline & & Total CVD & 0.5090 & 0.5161 & 0.5598 \\
\hline & & $\mathrm{VSI}_{\min }(\mathrm{p} . \mathrm{u})$ & 0.7438 & 0.7414 & 0.7255 \\
\hline & & $\mathrm{V}_{\min }(\mathrm{p} . \mathrm{u})$ & 0.9310 & 0.9299 & 0.9241 \\
\hline \multirow{6}{*}{ Case III } & \multirow{6}{*}{ Only REDG } & $\begin{array}{l}\text { Size in kW } \\
\text { (location) }\end{array}$ & $\begin{array}{l}520(18) \\
1730(61)\end{array}$ & $1828(61)$ & $1876(61)$ \\
\hline & & $\mathrm{P}_{\text {loss }}(\mathrm{kW})$ & 13.26 & 83.29 & 83 \\
\hline & & $\begin{array}{l}\% \mathrm{P}_{\text {loss }} \\
\text { Reduction }\end{array}$ & 93.95 & 62.98 & 63.11 \\
\hline & & Total CVD & 0 & 0 & 0 \\
\hline & & $\mathrm{VSI}_{\min }(\mathrm{p} . \mathrm{u})$ & 0.9587 & 0.8777 & 0.8788 \\
\hline & & $\mathrm{V}_{\min }(\mathrm{p} . \mathrm{u})$ & 0.9919 & 0.9679 & 0.9682 \\
\hline \multirow{7}{*}{ Case IV } & \multirow{7}{*}{$\begin{array}{l}\text { Simultaneous REDG } \\
\text { and DSTATCOM }\end{array}$} & $\begin{array}{l}\text { Size in kVAr } \\
\text { (location) }\end{array}$ & $350(18)$ & $1301(61)$ & $903.9(61)$ \\
\hline & & $\begin{array}{l}\text { Size in kW } \\
\text { (location) }\end{array}$ & $\begin{array}{l}520(18) \\
1740(61) \\
\end{array}$ & $1828(61)$ & $1080(62)$ \\
\hline & & $\mathrm{P}_{\text {loss }}(\mathrm{kW})$ & 8.37 & 23.17 & 38.6 \\
\hline & & $\begin{array}{l}\% \mathrm{P}_{\text {loss }} \\
\text { Reduction }\end{array}$ & 96.28 & 89.7 & 82.84 \\
\hline & & Total CVD & 0 & 0 & 0 \\
\hline & & $\mathrm{VSI}_{\min }(\mathrm{p} . \mathrm{u})$ & 0.9687 & 0.8943 & 0.8690 \\
\hline & & $\mathrm{V}_{\min }(\mathrm{p} . \mathrm{u})$ & 0.9942 & 0.9725 & 0.9562 \\
\hline
\end{tabular}

\section{CONCLUSION}

An appororiate place and size of REDGs and DSTATCOM in RDS has been identified using MBA. A new multi objective function framed with loss mitigation, bus voltage incremant, system stability improvement and total operating cost mitigation. The present approach has been tested and evaluated on 28-bus Indian rural distribution network and standard IEEE 69-bus RDS. The obtained results clarifies that integration of REDGs and DSTATCOM gives better outcomes. From presented results, it could be decided that the framed approach is exact in fine tuning the finest solutions. Further present methodology could be executed for any type of RDS.

\section{CONFLICTS OF INTEREST}

No conflict of interest was declared by the authors. 


\section{REFERENCES}

[1] Yuvaraj, T., Ravi, K., and Devabalaji, K, R., "DSTATCOM allocation in distribution networks considering load variations using bat algorithm", Ain Shams Engineering Journal, 8(3) 391-403, (2017).

[2] Devabalaji, K, R., Yuvaraj, T., and Ravi, K., "An efficient method for solving the optimal sitting and sizing problem of capacitor banks based on cuckoo search algorithm", Ain Shams Engineering Journal, 9(4) 589-597, (2016).

[3] Yuvaraj, T., Devabalaji, K, R., and Ravi, K., "Optimal placement and sizing of DSTATCOM using harmony search algorithm", Energy Procedia, 79: 759-765, (2015).

[4] Balamurugan, P.,Yuvaraj, T., and Muthukannan, P., "Simultaneous Allocation Renewable DGs and Capacitor for Typical Indian Rural Distribution Network using Cuckoo Search Algorithm", International Journal of Engineering \& Technology (UAE), 1011- 1016, (2018).

[5] Chaithra, C., and Padmaja, K., "Optimum placement of DSTATCOM using firefly algorithm for enhancing power quality", International Journal of Advanced Research in Computer and Communication Engineering, 4: 6, (2015).

[6] Rao, PVV Rama., and Sivanaga Raju, S., "Voltage regulator placement in radial distribution system using plant growth simulation algorithm", International Journal of Engineering, Science and Technology, 2-6, (2010).

[7] Devabalaji, K, R., Imran, A, M., Yuvaraj, T., and Ravi, K., "Power loss minimization in radial distribution system", Energy Procedia, 79: 917-923, (2015).

[8] Yuvaraj, T., Ravi, K., and Devabalaji, K, R., "DSTATCOM allocation in the radial distribution networks with different stability indices using bat algorithm", Gazi University Journal of Science, 30(4): 314-328, (2017).

[9] Suvarchala, K., Yuvaraj, T., and Balamurugan, P., "A brief review on optimal allocation of Distributed Generation in distribution network", $4^{\text {th }}$ International Conference on Electrical Energy Systems (ICEES). IEEE, (2018).

[10] Taher, S., A., and Seyed A., A., "Optimal location and sizing of DSTATCOM in distribution systems by immune algorithm", International Journal of Electrical Power \& Energy Systems, 60: 34-44, (2014).

[11] Chabok, B., S., and Ahmad A., "Optimal placement of D-STATCOMs into the radial distribution networks in the presence of distributed generations", American Journal of Electrical and Electronic Engineering, 4(2): 40-48, (2016).

[12] Balamurugan, P., Yuvaraj, T., and Muthukannan, P., "Optimal allocation of dstatcom in distribution network using whale optimization algorithm", Engineering, Technology \& Applied Science Research, 8(5): 3445-3449, (2018).

[13] Devabalaji, K, R., and Ravi, K., "Optimal size and siting of multiple dg and dstatcom in radial distribution system using bacterial foraging optimization algorithm", Ain Shams Engineering Journal, 7(3): 959-971, (2016). 
[14] Sanam, J., Sanjib G., and Panda, A., K., "Allocation of DSTATCOM and DG in distribution systems to reduce power loss using ESM algorithm", Power Electronics, Intelligent Control and Energy Systems (ICPEICES), IEEE International Conference on IEEE, (2016).

[15] Devi, S., and Geethanjali, M., "Optimal location and sizing determination of distributed generation and dstatcom using particle swarm optimization algorithm", International Journal of Electrical Power \& Energy Systems, 62: 562-570, (2014).

[16] Yuvaraj, T., Ravi, K., and Devabalaji, K, R., "Optimal allocation of DG and DSTATCOM in radial distribution system using cuckoo search optimization algorithm", Modelling and Simulation in Engineering, 2017, (2017).

[17] Thangaraj, Y., and Ravi, K., "Multi-objective simultaneous placement of DG and DSTATCOM using novel lightning search algorithm", Journal of Applied Research and Technology, 15(5): 477-491, (2017).

[18] Yang, X.-S.,"A New Metaheuristic Bat-Inspired Algorithm." Nature inspired cooperative strategies for optimization (NICSO 2010), Springer, Berlin, Heidelberg, 65-74, (2010).

[19] Yuvaraj, T., Devabalaji, K, R., and Ravi, K., "Optimal allocation of dg in the radial distribution network using bat optimization algorithm", Advances in Power Systems and Energy Management. Springer, Singapore, 563-569, (2018).

[20] Khushalani, S., and Noel S., "Unbalanced distribution power flow with distributed generation", In IEEE PES Transmission and Distribution Conference and Exhibition, 301-306. (2006).

[21] Parizad, A., Khazali, A., and Kalantar, M., "Optimal placement of distributed generation with sensitivity factors considering voltage stability and losses indices", $18^{\text {th }}$ Iranian Conference on Electrical Engineering, IEEE, 848-855, (2010).

[22] El-Fergany, A., "Optimal capacitor allocations using evolutionary algorithms", IET Generation, Transmission \& Distribution, 7(6): 593-601, (2013).

[23] Kowsalya, M., "Optimal size and siting of multiple distributed generators in distribution system using bacterial foraging optimization", Swarm and Evolutionary Computation, 15: 58-65, (2014).

[24] Singh, D., Devender S., and Verma, K, S., "Multiobjective optimization for DG planning with load models", IEEE Transactions on Power Systems, 24(1): 427-436, (2009).

[25] Hung, Duong Quoc, N., and Mithulananthan., and Bansal, R, C., "Integration of PV and BES units in commercial distribution systems considering energy loss and voltage stability", Applied Energy, 113: 1162-1170, (2014).

[26] Kayal, P., and Chanda, C., K., "Placement of wind and solar based DGs in distribution system for power loss minimization and voltage stability improvement", International Journal of Electrical Power \& Energy Systems, 53: 795-809, (2013).

[27] Muller, S, D., Marchetto, J., Airaghi, S., and Kournoutsakos, P., "Optimization based on bacterial chemotaxis", IEEE transactions on Evolutionary Computation, 6(1): 16-29, (2002).

[28] Yang, X., "Bat algorithm for multi-objective optimization", International Journal of Bio-Inspired Computation, 3(5): 267-274, (2011). 
[29] Kim, D., H., and Cho, C., H., "Bacteria Foraging Based Neural Network Fuzzy Learning" IICAI, (2005).

[30] Singh, R., K., and Goswami, S., K., "Multi-objective optimization of distributed generation planning using impact indices and trade-off technique." Electric Power Components and Systems, 39(11): 1175-1190, (2011).

[31] Das, D., Nagi, H, S., and Kothari, D, P., "Novel method for solving radial distribution networks", IEE Proceedings-Generation, Transmission and Distribution, 141(4): 291-298, (1994).

[32] Sahoo, N, C., and Prasad, K., "A fuzzy genetic approach for network reconfiguration to enhance voltage stability in radial distribution systems", Energy Conversion and Management, 47(18-19): 3288-3306, (2006).

[33] Kanwar, N., Gupta, N., Niazi, K, R., and Swarnkar, A., "Improved cat swarm optimization for simultaneous allocation of DSTATCOM and DGs in distribution systems", Journal of Renewable Energy, 2015, (2015). 